\title{
Stabilizing Motor Reflexive Activation and Acute Growth Hormone Response: A Systematic Review
}

John Jaquish", Henry Alkire and Kevin Hoesley

American Bone Health, Oakland, California, USA

"Corresponding author: Jaquish J, American Bone Health, Oakland, California, USA, E-mail: john@jirinstitute.com

Received date: June 12, 2016; Accepted date: July 08, 2016; Published date: July 13, 2016

Copyright: (c) 2016 Jaquish J, et al. This is an open-access article distributed under the terms of the Creative Commons Attribution License, which permits unrestricted use, distribution, and reproduction in any medium, provided the original author and source are credited.

\begin{abstract}
Objective: Evaluating reflexive (II and la afferent) body-stabilizing activity as a possible mechanism regulating hGH levels.

Data Sources: The authors searched MEDLINE, PubMed, Harvard HOLLIS, and EMBASE databases for studies published through 1 January 2016 by using such terms as: vibration, stability, and human growth hormone.

Study Selection: The authors included randomized, controlled trials and randomized pre-post observational trials that compared acute alterations of $\mathrm{hGH}$ in humans with both genders spanning from post-pubescence to elderly populations.
\end{abstract}

Data Extraction: Three authors independently reviewed articles and abstracted data.

Data Synthesis: PRISMA guidelines were followed with 17 articles describing 24 unique study populations meeting the inclusion criteria. A total of 265 participants who engaged in a destabilizing intervention were assayed both against baseline and control (when present). Populations varied in age, with all populations having a mean age of 35.1 [SD, 13.6], and RCTs of 41.6 [SD, 17.2], with the youngest population being 17.8 [SD, 0.88], and the oldest being 70 [SD, 8.8]. Subjects saw acute increases from pre-to-post of $647 \%$ [95\% Cl, 541\% to $753 \%](P=0.00001)$. Test group subjects compared to those subjected to control interventions increased hGH levels by $101 \%$ [95\% $\mathrm{Cl}$, $85.7 \%$ to $116 \%$ ] $(\mathrm{P}=0.006)$. Statistical analysis excluded one study that altered its blood sample concentrations via centrifuge.

Conclusions: The literature published on randomized, controlled trials and randomized acute evaluations of reflexive stability recruitment of muscle and $\mathrm{hGH}$ in multiple populations is limited but suggests that there is an association with whole body stability firing and hGH levels. On the basis of this evidence, interventions that encourage increases in whole body stability firing can be recommended to illicit increases in hGH levels.

Keywords: Pituitary axis; Muscle afferents; Human growth hormone; Hormone regulation

\section{Introduction}

While the link between physical activity and acute growth hormone response has been recognized since the 1960s [1,2], the results of analysis such as that performed by Shaner and researchers in 2014 demonstrates a marked increase over control subjects in hGH excitatory effect for exercises requiring self-stabilization from the subject compared to exercises without that requirement [3]. Further, a functional activity such as sprinting compared with endurance focused running has been shown to correlate with a greater hGH response of $82 \%$ [4] and $231 \%$ in earlier analysis [5]. Sprint type activity has been established to recruit the afferent stabilizing firing of muscle, further suggesting an hGH axis and stability firing relationship [6].

The relationship between hGH levels and stabilization was more precisely indicated by McCall, et al. [7], where it was demonstrated that the use of forced mechanical vibration to destabilize the tibialis anterior muscle produces an increase in plasma levels of bio-assayable
hGH. Notably McCall observes that levels of bioassayable hGH are not affected by stimulation of the soleous muscle. While McCall postulates that there is an excitatory effect for the production of this hormone in response to the recruitment of type I and IIa muscle spindle afferents through destabilization, the researchers also note that this excitatory activation may not be present in all muscles and may even be inhibitory in some cases.

The identification of a relationship between a form of hGH secretion and the activation of muscle afferents through destabilization of the tibialis anterior raises a question as to whether those results underlie a generic principle such that the application of destabilizing environments to all of the muscles in the body (and thus to all muscle spindle afferents) has a combined effect, excitatory or otherwise on the plasma levels of hGH.

The authors performed a systematic review and meta-analysis to evaluate existing data describing hGH serum level changes when a test subject's entire body is exposed to a destabilizing environment. Both pre to post observational trials and controlled experiments with a placebo group were considered. Changes in serum hGH postintervention or differences in hGH levels between treatment groups 
and control groups, as applicable by study type were evaluated. Analysis was performed to determine the impact of whole body muscle destabilization on hGH levels as illustrated by the body of currently published research.

\section{Methods}

\section{Literature search}

The authors developed a search strategy for identifying pertinent studies available on the MEDLINE, PubMed, Harvard HOLLIS, or EMBASE databases. Studies published through January 1, 2016 that were published in English or available in an English translation were queried using the search terms: "vibration," "stability," and "human growth hormone."

\section{Study selection}

Two kinds of randomized trials were selected: First, observational studies where serum hGH was measured before and immediately after the subject experienced a destabilizing intervention. Second, controlled studies where hGH was measured for a test group subjected to destabilizing intervention (and in some cases a concurrent selfstabilized exercise) and for a control group that was not subject to the destabilization based intervention. Data sets were excluded if motorized vibratory method was of imperceptible magnitude, and therefore reflected a stimulus too weak to achieve stabilizing activation of muscle afferents, which is the potential mechanism of action under analysis.

\section{Data abstraction}

All three authors independently reviewed the studies for compliance with selection criteria and then abstracted data for the analysis. These data were compared and resolved by repeated review.

\section{Data abstracted}

Authors abstracted data on each study including all reported hGH serum concentrations and standard deviations thereof, the number of study participants, the mean age of participants and the standard deviation of that average, the gender of participants, and whether any conflict of interest was disclosed. For included studies all of the above data was available.

\section{Quantitative data synthesis}

When evaluating changes in hGH concentration between pre-topost measurements of that metric for observational studies, we considered the results of each study using that change represented as a percentage of the mean pre value. The change was evaluated as a percentage of baseline because hGH concentrations measured prior to the destabilizing intervention varied tremendously between studies, regardless of the age of the participants. This suggested that the sensitivities of the hGH blood-work assays used may not have been consistent across different studies, while presumably being consistent within studies. Likewise, a similar potential exists for other variables impacting the value in certain studies, such as the protocol used in the centrifugal preparation of serum samples implemented in some studies but not described in detail. The PRISMA method of systematic review was followed in this analysis [8].
Results were evaluated for controlled studies using the same percentage type hGH metric, where the difference between mean test values and mean control values in each study was represented by that difference in means as a percentage of the mean control hGH level for the same study.

Pre-to-post observational studies were evaluated separately from controlled studies, and the results are averaged separately. When evaluating average impacts for either set of studies, mean percent changes were weighted based on the number of study participants. 95\% Confidence Intervals were calculated from standard deviations using a $\mathrm{Z}$ critical value of 1.96 .

Because only one study disclosed a conflict of interest, and that study yielded results that were very similar to other studies in its category, no penalty was applied to it in the calculation of average hGH concentration change for that category. That study is, however, designated as subject to conflict of interest in the results section where its results are depicted graphically and numerically alongside all other studies.

\section{Results}

Participants in evaluated studies varied widely in age. For pre-topost observational studies participants had a mean age of 35.1 [SD, 13.6]. The youngest of those study populations had a mean age of 17.8 [SD,0.88], and the oldest mean age was 70 [SD, 9.5]. For controlled studies the mean age was 41.6 [SD,17.2]. The youngest and oldest study population mean ages remained 17.8 [SD,0.88] and 70 [SD,9.5], respectively. Women comprised $23 \%$ of pre-to-post study population and $18 \%$ of controlled study population (Figure 1).

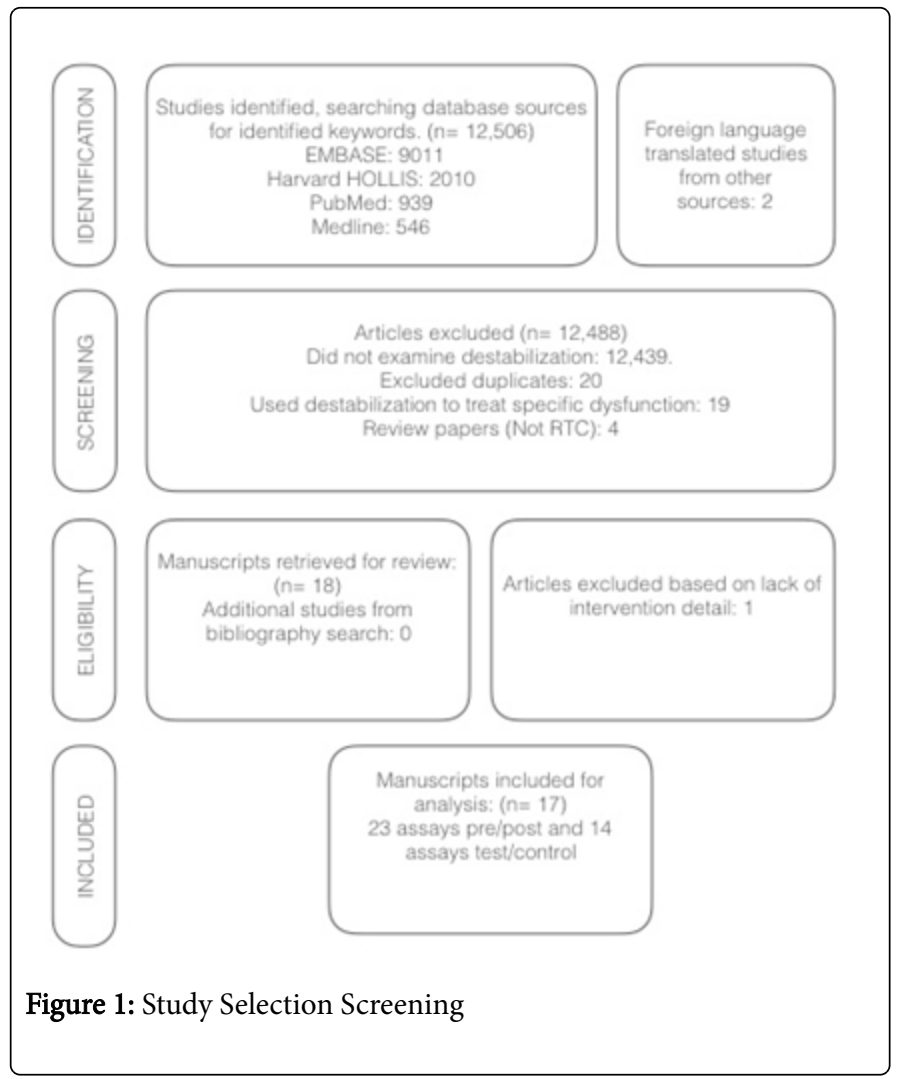




\section{Study characteristics}

Only one study fulfilled all evaluated study criteria/characteristics per Table 1, although all studies fulfilled at least two criteria and the mean number of criteria met by included studies was 4.1 out of 7 possible. Because some studies evaluated were pre-to-post observational, and the quality requirements indicated in Table 1 favor controlled studies, they are not universally satisfied.
Most studies were small, with mean size of 11 participants at completion. Study retention rates were high, with $98.3 \%$ of participants overall following through to completion of the study. No adverse events were reported. Destabilizing environments implemented in the evaluated studies were created using forced mechanical vibration in all cases. Destabilization characteristics varied significantly, with frequencies ranging from $12 \mathrm{~Hz}$ (Rahman) to $300 \mathrm{~Hz}$ (Iodice) and magnitudes as large as $5 \mathrm{~mm}$ (Sartorio) and as small as $1 \mathrm{~mm}$ (Fricke).

\begin{tabular}{|c|c|c|c|c|c|c|c|}
\hline Study & $\begin{array}{l}\text { Were Eligibility } \\
\text { Requirements } \\
\text { Stated? }\end{array}$ & $\begin{array}{l}\text { Was a } \\
\text { Placebo } \\
\text { Offered? }\end{array}$ & $\begin{array}{l}\text { Did Test and Control } \\
\text { Group Members } \\
\text { have Similar } \\
\text { Baseline } \\
\text { Characteristics? }\end{array}$ & $\begin{array}{l}\text { Were } \\
\text { Participants } \\
\text { Blinded? }\end{array}$ & $\begin{array}{l}\text { Unbiased } \\
\text { analysis? }\end{array}$ & $\begin{array}{l}\text { Were } \\
\text { Clinicians } \\
\text { Blinded? }\end{array}$ & $\begin{array}{lr}\text { Was Destabilization } \\
\text { Protocol } & \text { Clearly } \\
\text { Defined r using } \\
\text { Quantifiable } \\
\text { Metrics? }\end{array}$ \\
\hline Bosco et al. [9] & $\bullet$ & $\circ$ & N/A & $\circ$ & $\circ$ & $\circ$ & • \\
\hline Cardinale et al. [10] & $\bullet$ & $\bullet$ & $\bullet$ & $\bullet$ & $\bullet$ & $\circ$ & - \\
\hline DiLoreto et al. [11] & $\bullet$ & $\bullet$ & $\bullet$ & --- & $\bullet$ & $\circ$ & - \\
\hline DiGimiani et al. [12] & - & $\bullet$ & $\bullet$ & $\bullet$ & $\bullet$ & $\bullet$ & - \\
\hline Elmantazer, et al. [13] & $\bullet$ & $\circ$ & N/A & $\circ$ & $\bullet$ & 0 & - \\
\hline Fricke et al. [14] & $\bullet$ & $\circ$ & N/A & $\circ$ & $\bullet$ & 0 & - \\
\hline Goto et al. [15] & - & $\circ$ & N/A & $\circ$ & • & $\circ$ & • \\
\hline Guinta et al. [16] & $\bullet$ & $\circ$ & N/A & $\circ$ & • & 0 & $\circ$ \\
\hline Guinta et al. [17] & • & $\bullet$ & $\bullet$ & $\circ$ & $\bullet$ & $\circ$ & $\circ$ \\
\hline Guo-Shing et al. [18] & • & $\bullet$ & $\bullet$ & --- & $\bullet$ & o & $\circ$ \\
\hline lodice et al. [19] & • & $\bullet$ & $\bullet$ & --- & • & $\circ$ & • \\
\hline Kvorning et al. [20] & • & • & $\bullet$ & -- & $\bullet$ & 0 & - \\
\hline McCall et al. & - & ○ & N/A & $\circ$ & - & $\circ$ & - \\
\hline Rahman et al. [21] & - & $\bullet$ & $\bullet$ & --- & • & $\circ$ & $\circ$ \\
\hline Sartorio et al. [22] & - & • & • & $\circ$ & • & $\circ$ & - \\
\hline Seok et al. [23] & $\bullet$ & $\bullet$ & $\bullet$ & --- & • & $\circ$ & --- \\
\hline
\end{tabular}

Table 1: Study Criteria/Characteristics.

\section{Quantitative data synthesis}

Observational pre/post: All studies report hGH serum values, as this was a prerequisite for study consideration. For the 22 pre-to-post test groups evaluated, every sample indicated an increase in serum growth hormone following the intervention, and showed statistical significance $(\mathrm{p}<0.05)$ independently. Intervention characteristic matrices found in Appendix 1 and Appendix 2.

The mean change in hGH level was $647 \%$ [ $95 \%$ CI, $541 \%$ to $753 \%$ ] $(\mathrm{P}=0.00001)$ for all of the assays combined. Mean change analysis excluded one study that altered its blood sample concentrations via centrifuge (McCall). The least hGH response was seen in Cardinale et al., (mean increase of 64.7\%), and the greatest was from Kvorning et al (mean increase of 2800\%) (Figure 2).

RTCs: For the RCTs, the mean increase in GH was 101\% [95\% CI, $85.7 \%$ to $116 \%$ ] (P 0.006). Of the 13 RCTs evaluated here, three studies showed increases that were not statistically significant individually, while the remaining 10 studies indicated significant increases. The greatest mean change in serum concentration for any study group was 318\% (Kvorning) (Figure 3).

\section{Limitations}

Some of the included controlled studies had stability firing type activity as a control intervention (e.g., free-weight squat exercises). The objective of this analysis was to determine the relationship between specific reflexive (Il and Ia afferent) body-stabilizing firing and hGH levels, and since these control data sets may have elicited increases in hGH by this same mechanism, resulting findings are less impactful. Most of the studies included small sample sizes and most studies applied interventions to younger populations. 


\section{Safety of the Intervention}

No adverse events were documented during any study.

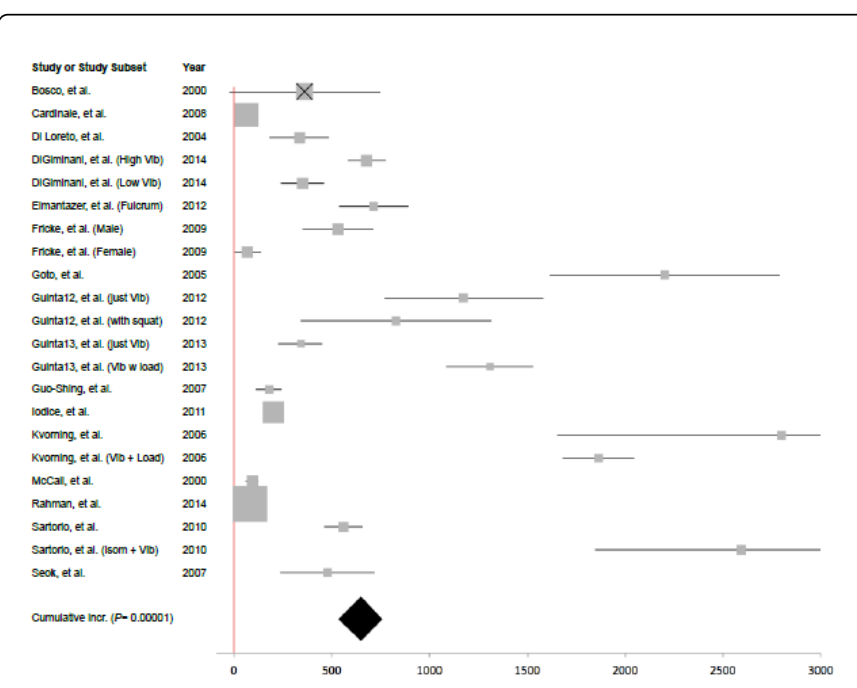

Figure 2: Pre/Post forest plot.

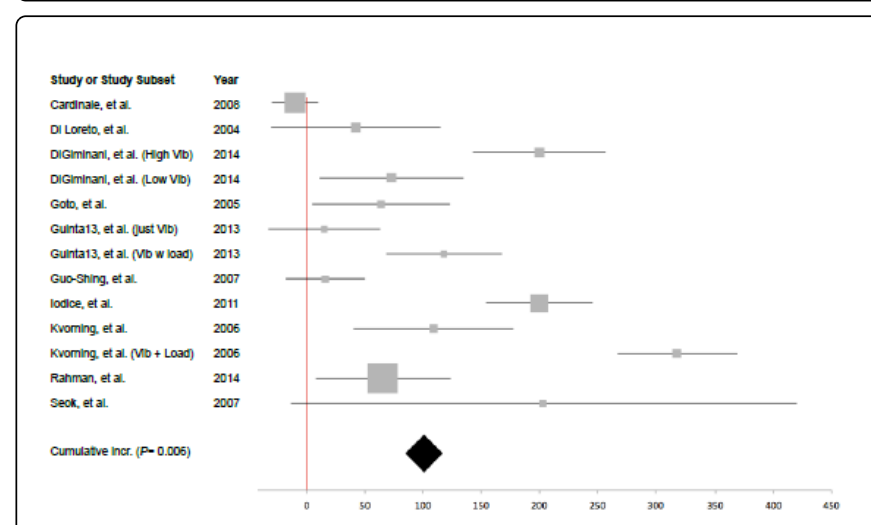

Figure 3: RTC forest plot.

\section{Discussion}

It has long been established that exercise causes an acute release of $\mathrm{hGH}$, but the underlying mechanism (or mechanisms) remain unclear. Existing literature review on the physiological processes underlying hGH release during exercise by Godfrey et al. hypothesizes a muscle afferent pituitary axis [24]. For hGH as measured through standard immunoassays Godfrey found that most studies evaluated in the analysis indicate that hGH release occurs following exercise of sufficient intensity, which is consistent with possible muscle afferent neural modulation of the pituitary, but is not sufficient evidence to rule out other exercise related physiological changes as possible signaling mechanisms, such as Catecholamine or lactate release, $\mathrm{pH}$ balance changes, or especially Nitric Oxide release. This inability to more narrowly characterize a physiological mechanism in the Godfrey analysis is a result of the conventional exercise protocols that were assayed, because these would be expected to simultaneously induce activity in all of the aforementioned signaling mechanisms. The unique data set considered in Godfrey's review that avoided this problem, is the McCall, et al. data involving destabilization of individual muscles in situ using forced mechanical vibrations. That study demonstrated significant increases in isoforms of $\mathrm{hGH}$, but only involved the destabilization of individual muscles, effectively isolating a destabilizing environment for study of attenuating afferent muscle activation and $\mathrm{hGH}$.

As the mechanism of interest is the stabilizing firing of muscle afferents, particularly those associated with fast-twitch muscles, this analysis identified studies with destabilizing-environment interventions. Thus while the evaluation was not deliberately construed so as to only involve a single modality, the unique intervention available in current research which met these criteria was that wherein the subject stood on a destabilizing surface. Vibratory destabilization interventions are particularly appropriate as McCall's research, the inspiration for this analysis, used this modality to elicit the hypothesized reflexive firing of muscle afferents and associated hGH release.

The destabilizing environments applied during the various studies evaluated herein varied tremendously in magnitude and frequency. This contributes greatly to the evidentiary quality of the data in the context of testing the hypothesis that stabilizing muscle afferent activation leads to hGH release, since that premise should be tested with a heterogeneous variety of destabilizing stimuli to understand a general relationship between that kind of stimuli and corresponding serum hGH level release. This also helps avoid falsely generalizing an effect only present with some single specific pattern of vibration. In fact, despite the wide variety of destabilizing protocols used to obtain the evaluated data, across 24 test groups and nearly as many distinct (albeit similar) treatment protocols, three failed to demonstrate significance. However, these three did show a mean increase in hGH levels vs control. Further, the three test cohorts vs control groups that did not reach significance are from small datasets which likely demonstrate a lack of significance only for the lack of a larger sample size.

It is also apparent that pre-to-post delta values for serum hGH levels are much greater than equivalent values comparing test and control groups in the controlled studies. This is consistent with the current understanding of exercise triggered hGH release, possibly due to some controlled studies using alternative exercise as a placebo treatment where the alternative exercise either included a self-stabilization component or was an entirely self-stabilized exercise, both of which would potentially trigger muscle afferents similar but less so than that of the test interventions. Thus the very large changes in serum hGH levels seen in the pre-to-post literature are more telling in the context of our hypothesis.

Variance of increase in hGH were seen with the lowest response at $64.7 \%$ (Cardinale), and the greatest at $2800 \%$ (Kvorning). The differences in protocol were pronounced as well. The Cardinale protocol included two legs with slight knee flexion for 1-minute bouts. Kvorning applied instability to two subject cohorts that both maintained a two-legged 90-degree knee bend for 30 seconds per bout. One subject cohort used a weighted bar resting stabilized behind the neck, weighing $80 \%$ of the subjects 1 rep maximum, and the other alternate cohort held a wooden broomstick handle on their shoulders. While the weighted bar destabilized cohort showed the greatest increase of hGH at $2800 \%$, the near weightless wooden broomstick handle cohort produced an increase of 1865\%. Though EMG levels were not measured in either intervention, the afferent activation is 
known to be greater with a deeper knee bend. The Cardinale protocol placed little demand on muscle afferents, as the positioning of the subjects was slightly greater than that of tonic contraction, and thereby would be expected to elicit a lesser response. The contrast between these two data sets and assay modalities may strengthen indications of a stability firing mechanism as the source of the contrast between the lowest response at $64.7 \%$, and the greatest at $2800 \%$.

Although study characteristics do not score highly on the criteria metrics, that does not detract from the value of the current volume of research into this matter. Specifically, pre-to post literature is not controlled, or blinded, which leads to low scores on our metric even for well-conducted studies with no bias or conflict of interest declared. Only hGH serum levels were evaluated which are a quantifiable biochemical metric measured by immunoassay where results are observed by computer measurement of permeability to electromagnetic radiation. Therefore, selection bias on the part of the researchers seems unlikely. Further, deliberate auto-regulation of hGH

by a human as a result of the placebo effect or otherwise has never been demonstrated, so it would not diminish the value of the hypothesized mechanism if it were the case that subjects increase their hGH levels only in presence of a known destabilizing environment.

By combining all the data available there is a stronger indication of a relationship between afferent stability firing and acute hGH increases than was previously understood.

\section{Role of the Funding Sources}

The authors were supported by Performance Health Systems LLC, The funding source had no role in the design, collection, or reporting of the data or study, or in the decision to submit the analysis for publication.

\section{Appendix}

\begin{tabular}{|c|c|c|c|c|c|c|c|c|c|c|}
\hline Study & Year & Ctrl & Baseline GH & Post Test GH & Delta GH & $\begin{array}{l}\text { Sample } \\
\text { Size }\end{array}$ & $\begin{array}{l}\text { Participant } \\
\text { Age }\end{array}$ & $M / F$ & Bias & Notes \\
\hline Bosco et al. [9] & 2000 & $\mathrm{~N}$ & $\begin{array}{l}6.2 \pm 16.2 \\
\mathrm{ng} / \mathrm{ml}\end{array}$ & $28.6 \pm 29.6 \mathrm{ng} / \mathrm{ml}$ & $+22.4 \pm 45.8 \mathrm{ng} / \mathrm{ml}$ & 14 & $25 \pm 4.6$ & $14 / 0$ & $\mathrm{Y}$ & \\
\hline Cardinal et al. [10] & 2008 & $\mathrm{Y}$ & $1.6 \pm .3 \mu \mathrm{lU} / \mathrm{ml}$ & $2.7 \pm 0.7 \mu \mathrm{lU} / \mathrm{ml}$ & $+1.1 \pm 1 \mu \mathrm{lU} / \mathrm{ml}$ & 20 & $70(66,85)$ & $9 / 11$ & N & \\
\hline Di Loreto et al. [11] & 2004 & Y & $1.7 \pm 0.6 \mu \mathrm{lU} / \mathrm{ml}$ & $7.4 \pm 3.6 \mu \mathrm{lU} / \mathrm{ml}$ & $+5.7 \pm 4.2 \mu \mathrm{lU} / \mathrm{ml}$ & 10 & $39 \pm 3$ & $10 / 0$ & N & \\
\hline DiGiminani et al. [12] & 2014 & $\mathrm{Y}$ & $50 \pm 20 \mathrm{nM}$ & $390 \pm 60 \mathrm{nM}$ & $+340 \pm 80 \mathrm{nM}$ & 10 & $25 \pm 0.9$ & $10 / 0$ & $\mathrm{~N}$ & \\
\hline DiGiminaniet al. [12] & 2014 & Y & $50 \pm 20 \mathrm{nM}$ & $225 \pm 70 \mathrm{nM}$ & $+175 \pm 90 \mathrm{nM}$ & 10 & $25 \pm 0.9$ & $10 / 0$ & N & \\
\hline Elmantazer et al. [13] & 2012 & N & $\begin{array}{l}0.07 \\
\mathrm{ng} / \mathrm{ml}\end{array} \quad \pm \quad 0.1$ & $0.57 \pm 0.1 \mathrm{ng} / \mathrm{ml}$ & $+0.5 \pm 0.2 \mathrm{ng} / \mathrm{ml}$ & 10 & $33(29,49)$ & $10 / 0$ & N & \\
\hline $\begin{array}{l}\begin{array}{l}\text { Fricke et al. [14] } \\
\text { (Male) }\end{array} \\
\end{array}$ & 2009 & $\mathrm{~N}$ & $\begin{array}{l}0.250 \pm 0.216 \\
\mathrm{ng} / \mathrm{ml}\end{array}$ & $1.58 \pm 0.51 \mathrm{ng} / \mathrm{ml}$ & $+1.33 \pm .726 \mathrm{ng} / \mathrm{ml}$ & 10 & $32.1 \pm 5.8$ & $10 / 0$ & $\mathrm{~N}$ & \\
\hline Fricke et al. [14] & 2009 & $\mathrm{~N}$ & $\begin{array}{l}8.807 \pm 7.570 \\
\mathrm{ng} / \mathrm{ml}\end{array}$ & $\begin{array}{l}15.017 \\
\mathrm{ng} / \mathrm{ml}\end{array} \quad \pm 1.879$ & $\begin{array}{l}+6.21 \\
\mathrm{ng} / \mathrm{ml}\end{array} \quad \pm \quad 9.449$ & 10 & $32 \pm 6.9$ & $0 / 10$ & $\mathrm{~N}$ & \\
\hline Goto et al. [15] & 2005 & $\mathrm{Y}$ & $\begin{array}{l}0.2 \\
\mathrm{ng} / \mathrm{ml}\end{array}$ & $4.6 \pm 1.7 \mathrm{ng} / \mathrm{ml}$ & $+4.4 \pm 1.701 \mathrm{ng} / \mathrm{ml}$ & 8 & $23.4 \pm 0.9$ & $8 / 0$ & $\mathrm{~N}$ & \\
\hline Guinta et al. [16] (Vib) & 2012 & $\mathrm{~N}$ & $0.4 \pm 0.3 \mathrm{ng} / \mathrm{ml}$ & $5.1 \pm 1.9 \mathrm{ng} / \mathrm{ml}$ & $+4.7 \pm 2.2 \mathrm{ng} / \mathrm{ml}$ & 7 & $22 \pm 5$ & $0 / 7$ & N & \\
\hline Guinta et al. [16] & 2012 & $\mathrm{~N}$ & $0.7 \pm 0.9 \mathrm{ng} / \mathrm{ml}$ & $6.5 \pm 3.7 \mathrm{ng} / \mathrm{ml}$ & $+5.8 \pm 4.6 \mathrm{ng} / \mathrm{ml}$ & 7 & $22 \pm 5$ & $0 / 7$ & $\mathrm{~N}$ & \\
\hline Guinta et al. [17] & 2013 & $\mathrm{Y}$ & $2.2 \pm 0.4 \mathrm{ng} / \mathrm{ml}$ & $9.7 \pm 2.7 \mathrm{ng} / \mathrm{ml}$ & $+7.5 \pm 3.1 \mathrm{ng} / \mathrm{ml}$ & 6 & $27.7 \pm 1.3$ & $0 / 6$ & $\mathrm{~N}$ & \\
\hline Guinta et al. [17] & 2013 & $\mathrm{Y}$ & $1.3 \pm 0.6 \mathrm{ng} / \mathrm{ml}$ & $18.3 \pm 3.0 \mathrm{ng} / \mathrm{ml}$ & $+17 \pm 3.6 \mathrm{ng} / \mathrm{ml}$ & 6 & $27.7 \pm 1.3$ & $0 / 6$ & $\mathrm{~N}$ & \\
\hline Guo-Shing et al. [18] & 2007 & $\mathrm{Y}$ & $\begin{array}{l}3.39 \\
\mathrm{ng} / \mathrm{ml}\end{array} \pm 0.91$ & $9.43 \pm 2.39 \mathrm{ng} / \mathrm{ml}$ & $+6.04 \pm 3.3 \mathrm{ng} / \mathrm{ml}$ & 8 & $17.8 \pm 0.88$ & $8 / 0$ & $\mathrm{~N}$ & \\
\hline lodice et al. [19] & 2011 & $\mathrm{Y}$ & $\begin{array}{l}0.1 \pm 0.01 \\
\mathrm{ng} / \mathrm{ml}\end{array}$ & $0.3 \pm 0.05 \mathrm{ng} / \mathrm{ml}$ & $+0.2 \pm .06 \mathrm{ng} / \mathrm{ml}$ & 18 & $21 \pm 1.4$ & $18 / 0$ & $\mathrm{~N}$ & \\
\hline Kvorning et al. [20] & 2006 & $\mathrm{Y}$ & $\begin{array}{l}0.24 \pm 0.17 \\
\mu \mathrm{lU} / \mathrm{ml}\end{array}$ & $11.6 \pm 3.80 \mu \mathrm{lU} / \mathrm{ml}$ & $\begin{array}{l}+11.36 \quad \pm \quad 3.97 \\
\mu \mathrm{lU} / \mathrm{ml}\end{array}$ & 8 & $23 \pm 0.7$ & $8 / 0$ & $\mathrm{~N}$ & \\
\hline Kvorning et al. [20] & 2006 & $\mathrm{Y}$ & $\begin{array}{l}1.17 \pm 0.81 \\
\mu \mathrm{lU} / \mathrm{ml}\end{array}$ & $23 \pm 2.3 \mu \mathrm{lU} / \mathrm{ml}$ & $\begin{array}{l}+21.83 \\
\mu \mathrm{l} U / \mathrm{ml}\end{array} \quad \pm \quad 3.11$ & 8 & $23 \pm 0.6$ & $8 / 0$ & $\mathrm{~N}$ & \\
\hline McCall et al. & 2000 & $\mathrm{~N}$ & $\begin{array}{l}1216 \\
\mathrm{ng} / \mathrm{ml}\end{array} \quad \pm 148$ & $2362 \pm 487 \mathrm{ng} / \mathrm{ml}$ & $+1146 \pm 635 \mathrm{ng} / \mathrm{ml}$ & 10 & $26.7 \pm 1.6$ & $10 / 0$ & $\mathrm{~N}$ & * \\
\hline Rahman et al. [21] & 2014 & $\mathrm{Y}$ & $\begin{array}{l}6.4 \pm 5.07 \\
\mathrm{ng} / \mathrm{ml}\end{array}$ & $11.6 \pm 3.80 \mathrm{ng} / \mathrm{ml}$ & $+5.2 \pm 8.87 \mathrm{ng} / \mathrm{ml}$ & 30 & $62-75$ & $30 / 0$ & $\mathrm{~N}$ & \\
\hline
\end{tabular}


Citation: Jaquish J, Alkire H, Hoesley K (2016) Stabilizing Motor Reflexive Activation and Acute Growth Hormone Response: A Systematic

\begin{tabular}{|c|c|c|c|c|c|c|c|c|c|}
\hline Sartorio et al. [22] & 2010 & N & $\begin{array}{l}0.34 \\
\mathrm{ng} / \mathrm{ml}\end{array}$ & $4.8 \pm 0.5 \mathrm{ng} / \mathrm{ml}$ & $+4.46 \pm .506 \mathrm{ng} / \mathrm{ml}$ & 9 & $23 \pm 2$ & $9 / 0$ & $\mathrm{~N}$ \\
\hline Sartorio et al. [22] & 2010 & N & $\begin{array}{l}0.44 \\
\mathrm{ng} / \mathrm{ml}\end{array}$ & $18 \pm 5.0 \mathrm{ng} / \mathrm{ml}$ & $\begin{array}{l}+17.56 \quad \pm \quad 5.01 \\
\mathrm{ng} / \mathrm{ml}\end{array}$ & 9 & $23 \pm 2$ & $9 / 0$ & $\mathrm{~N}$ \\
\hline Seok et al. [23] & 2007 & $Y$ & $\begin{array}{l}0.96 \\
\mathrm{ng} / \mathrm{ml}\end{array}$ & $5.55 \pm 3.12 \mathrm{ng} / \mathrm{ml}$ & $+4.59 \pm 3.13 \mathrm{ng} / \mathrm{ml}$ & 7 & $25.4 \pm 2.2$ & $0 / 7$ & $\mathrm{~N}$ \\
\hline
\end{tabular}

Appendix 1: Pre/Post data table.

\begin{tabular}{|c|c|c|c|c|c|c|c|c|c|c|}
\hline Study & Year & $\begin{array}{l}\text { Control } \\
\text { GH }\end{array}$ & Test GH & Delta GH & $\begin{array}{l}\text { Sample } \\
\text { Size }\end{array}$ & $\begin{array}{l}\text { Participant } \\
\text { Age }\end{array}$ & $M / F$ & $P$ Value & Bias & Notes \\
\hline Cardinale et al. [10] & 2008 & $\begin{array}{l}3 \underset{\mu \mathrm{UU} / \mathrm{ml}}{ \pm} 0.7\end{array}$ & $2.7 \pm 0.7 \mu \mathrm{lU} / \mathrm{ml}$ & $-0.3 \pm 1.4 \mu \mathrm{lU} / \mathrm{ml}$ & 20 & $70(66,85)$ & $9 / 11$ & 0.4 & $\mathrm{~N}$ & * \\
\hline Di Loreto et al. [11] & 2004 & $\begin{array}{l}5.2 \pm 2.5 \\
\mu \mathrm{lU} / \mathrm{ml}\end{array}$ & $7.4 \pm 3.6 \mu \mathrm{lU} / \mathrm{ml}$ & $+2.2 \pm 6.1 \mu \mathrm{lU} / \mathrm{ml}$ & 10 & $39 \pm 3$ & $10 / 0$ & 0.216 & $\mathrm{~N}$ & \\
\hline DiGiminani et al. [12] & 2014 & $\begin{array}{l}130 \pm 60 \\
n M\end{array}$ & $390 \pm 60 \mathrm{nM}$ & $+260 \pm 120 \mathrm{nM}$ & 10 & $25 \pm 0.9$ & $10 / 0$ & 0.003 & $\mathrm{~N}$ & \\
\hline DiGiminani et al. [12] & 2014 & $\begin{array}{l}130 \pm 60 \\
n M\end{array}$ & $225 \pm 70 \mathrm{nM}$ & $+95 \pm 130 \mathrm{nM}$ & 10 & $25 \pm 0.9$ & $10 / 0$ & 0.003 & $\mathrm{~N}$ & \\
\hline Goto et al. [15] & 2005 & $\begin{array}{l}2.8 \pm 1.2 \\
\mathrm{ng} / \mathrm{ml}\end{array}$ & $4.6 \pm 1.7 \mathrm{ng} / \mathrm{ml}$ & $+1.8 \pm 2.4 \mathrm{ng} / \mathrm{ml}$ & 8 & $23.4 \pm 0.9$ & $8 / 0$ & 0.453 & $\mathrm{~N}$ & \\
\hline Guinta et al. [17] & 2013 & $\begin{array}{l}8.4 \pm 2.3 \\
\mathrm{ng} / \mathrm{ml}\end{array}$ & $9.7 \pm 2.7 \mathrm{ng} / \mathrm{ml}$ & $+1.3 \pm 5 \mathrm{ng} / \mathrm{ml}$ & 6 & $27.7 \pm 1.3$ & 0/6 & 0.05 & $\mathrm{~N}$ & \\
\hline Guinta et al. [17] & 2013 & $\begin{array}{l}8.4 \pm 2.3 \\
\mathrm{ng} / \mathrm{ml}\end{array}$ & $18.3 \pm 3.0 \mathrm{ng} / \mathrm{ml}$ & $+9.9 \pm 5.3 \mathrm{ng} / \mathrm{ml}$ & 6 & $27.7 \pm 1.3$ & $0 / 6$ & 0.05 & $\mathrm{~N}$ & \\
\hline Guo-Shing et al. [18] & 2007 & $\begin{array}{l}8.15 \pm 1.62 \\
\mathrm{ng} / \mathrm{ml}\end{array}$ & $9.43 \pm 2.39 \mathrm{ng} / \mathrm{ml}$ & $+1.28 \pm 4 \mathrm{ng} / \mathrm{ml}$ & 8 & $17.8 \pm 0.88$ & $16 / 0$ & 0.05 & $\mathrm{~N}$ & \\
\hline lodice et al. [19] & 2011 & $\begin{array}{l}0.1 \pm 0.05 \\
\mathrm{ng} / \mathrm{ml}\end{array}$ & $0.3 \pm 0.05 \mathrm{ng} / \mathrm{ml}$ & $+0.2 \pm 0.1 \mathrm{ng} / \mathrm{ml}$ & 18 & $21 \pm 1.4$ & $18 / 0$ & 0.05 & $\mathrm{~N}$ & \\
\hline Kvorning et al. [20] (Vib) & 2006 & $\begin{array}{l}5.5 \quad \pm \quad 2 \\
\mu \mathrm{lU} / \mathrm{ml}\end{array}$ & $11.6 \pm 3.80 \mu \mathrm{lU} / \mathrm{ml}$ & $+6.1 \pm 5.8 \mu \mathrm{lU} / \mathrm{ml}$ & 9 & $23 \pm 0.7$ & $28 / 0$ & 0.05 & $\mathrm{~N}$ & \\
\hline Kvorning et al. [20] & 2006 & $\begin{array}{l}5.5 \quad \pm \quad 2 \\
\mu \mathrm{lU} / \mathrm{ml}\end{array}$ & $23 \pm 2.3 \mu \mathrm{lU} / \mathrm{ml}$ & $+17.5 \pm 4.3 \mu \mathrm{lU} / \mathrm{ml}$ & $9 / 10$ & $23 \pm 0.6$ & $28 / 0$ & 0.05 & $\mathrm{~N}$ & \\
\hline Rahman et al. [21] & 2014 & $\begin{array}{l}7.0 \pm 7.6 \\
\mathrm{ng} / \mathrm{ml}\end{array}$ & $11.6 \pm 3.80 \mathrm{ng} / \mathrm{ml}$ & $+4.6 \pm 11.4 \mathrm{ng} / \mathrm{ml}$ & 30 & $62-75$ & $60 / 0$ & 0.05 & $\mathrm{~N}$ & \\
\hline Seok et al. [23] & 2007 & $\begin{array}{l}1.83 \pm 2.24 \\
\mathrm{ng} / \mathrm{ml}\end{array}$ & $5.55 \pm 3.12 \mathrm{ng} / \mathrm{ml}$ & $\begin{array}{l}+3.72 \\
\mathrm{ng} / \mathrm{ml}\end{array} \quad \pm \quad 5.36$ & 7 & $24.9 \pm 4.1$ & 0/14 & 0.05 & $\mathrm{~N}$ & \\
\hline
\end{tabular}

Appendix 2: RTC data table.

\section{References}

1. Schalch DS (1967) The influence of physical stress and exercise on growth hormone and insulin secretion in man. J Lab Clin Med 69: 256-269.

2. Hunter WM, Fonseka CC, Passmore R (1965) Growth hormone: important role in muscular exercise in adults. Science 150: 1051-1053.

3. Shaner AA, Vingren JL, Hatfield DL, Budnar RG, Duplanty AA, et al. (2014) The acute hormonal response to free weight and machine weight resistance exercise. J Strength Cond Res 28: 1032-1040.

4. Nevill ME, Holmyard DJ, Hall GM, Allsop P, Oosterhout VA, et al. (1996) Growth hormone responses to treadmill sprinting in sprint- and endurance- trained athletes. Eur J Appl Physiol Occup Physiol 72: 460-467.

5. Vanhelder WP, Goode RC, Radomski MW (1984) Effect of anaerobic and aerobic exercise of equal duration and work expenditure on plasma growth hormone levels. Eur J Appl Physiol Occup Physiol 52: 255-257.

6. Ross A, Leveritt M, Riek S (2001) Neural influences on sprint running: training adaptations and acute responses. Sports Med 31: 409-425.

7. McCall GE, Grindeland RE, Roy RR, Edgerton VR (2000) Muscle afferent activity modulates bioassayable growth hormone in human plasma. J Appl Physiol 89: 1137-1141. 
Citation: Jaquish J, Alkire H, Hoesley K (2016) Stabilizing Motor Reflexive Activation and Acute Growth Hormone Response: A Systematic

8. Moher D, Liberati A, Tetzlaff J, Altman DG, (2009) Preferred reporting items for systematic reviews and meta-analyses: the PRISMA statement. Ann Intern Med 151: 264-269.

9. Bosco C, Iacovelli M, Tsarpela O, Cardinale M, Bonifazi M, et al. (2000) Hormonal responses to whole-body vibration in men. Eur J Appl Physiol 81: 449-454.

10. Cardinale M, Soiza RL, Leiper JB, Gibson A, Primrose WR (2008) Hormonal responses to a single session of whole body vibration exercise in older individuals. Br J Sports Med 44: 284-288.

11. Di Loreto C, Ranchelli A, Lucidi P, Murdolo G, Parlanti N, et al. (2004) Effects of whole-body vibration exercise on the endocrine system of healthy men. J Endocrinol Invest 27: 323-327.

12. Di Giminiani R, Fabiani L, Baldini G, Cardelli G, Giovannelli A, et al. (2014) Hormonal and neuromuscular responses to mechanical vibration applied to upper extremity muscles. PloS one 9: e111521.

13. Elmantaser M, McMillan M, Smith K, Khanna S, Chantler D, et al. (2012). A comparison of the effect of two types of vibration exercise on the endocrine and musculoskeletal system. J Musculoskelet Neuronal Interact 12: 144-154.

14. Fricke O, Semler O, Land C, Beccard R, Thoma P, et al. (2009). Hormonal and metabolic responses to whole body vibration in healthy adults. The Endocrinologist 19: 24-30.

15. Goto K, Takamatsu K (2005). Hormone and lipolytic responses to whole body vibration in young men. Jpn J Physiol 55: 279-284.

16. Giunta M, Cardinale M, Agosti F, Patrizi A, Compri E, et al. (2012) Growth hormone-releasing effects of whole body vibration alone or combined with squatting plus external load in severely obese female subjects. Obes Facts 5: 567-574.
17. Giunta M, Rigamonti AE, Agosti F, Patrizi A, Compri E, et al. (2013) Combination of external load and whole body vibration potentiates the GH-releasing effect of squatting in healthy females. Horm Metab Res 45: 611-616.

18. Guo-Shing H, Huey-June W, Ching-Wen C, Wai-Ling C (2007) The effect of resistive strength training with whole body vibration stimulus on muscular strength and serotonin. Journal of Exercise Physiology and Fitness 157-167.

19. Iodice P, Bellomo RG, Gialluca G, Fanò G, Saggini R (2011) Acute and cumulative effects of focused high-frequency vibrations on the endocrine system and muscle strength. Eur J Appl Physiol 111: 897-904.

20. Kvorning T, Bagger M, Caserotti P, Madsen K (2006) Effects of vibration and resistance training on neuromuscular and hormonal measures. Eur J Appl Physiol 96: 615-625.

21. Rahman S, Hagag A (2014) Muscular and Hormonal Responses to Whole Body Vibration Exercises in Elderly. World Applied Sciences Journal 32: 1775-1779.

22. Sartorio A, Lafortuna CL, Maffiuletti NA, Agosti F, Marazzi N, et al. (2010) GH responses to two consecutive bouts of whole body vibration, maximal voluntary contractions or vibration alternated with maximal voluntary contractions administered at 2 -h intervals in healthy adults. Growth Horm IGF Res 20: 416-421.

23. Seok H (2007) Effects of vibration exercise on the physical fitness and the hormone of adults with mental retardation. The Korean Journal of Physical Education 46: 633-641.

24. Godfrey RJ, Madgwick Z, Whyte GP (2003) The exercise-induced growth hormone response in athletes. Sports Medicine 33: 599-613. 